\title{
IMPACT OF EMPOWERING LOCAL STAKEHOLDERS IN TOURISM DEVELOPMENT AND SUSTAINABILITY OF MARGINAL RURAL SETTLEMENTS IN IRAN
}

\author{
SHAFIEI SABET NASER \& HARATIFARD SAEIDEH \\ Human Geography Department, Shahid Beheshti University, Iran
}

\begin{abstract}
The involvement and cooperation of local stakeholders in tourism activities in rural settlements and tourism destinations not only attracts more tourists, but also develops infrastructure, income distribution, and wealth generation, and consequently the sustainability of these marginal rural settlements. In Iran, however, the role of local stakeholders in policy making for the development of tourism has not been clearly defined. Thus, scant attention has been paid to the empowering of local stakeholders of tourism in policymaking. Against this backdrop, this study adopts a descriptiveanalytical method to explore the impacts of empowering local stakeholders of tourism on the development and sustainability of rural settlements and tourist destinations in the marginal areas of Tehran and Alborz. To assess sustainability and development of marginal rural settlements, rural development factors in areas such as environmental, ecological, social, economic and physicalinfrastructural dimensions were analysed. Also, the variable of empowering local stakeholders of tourism was measured in terms of 10 indicators, including education and awareness-raising, knowledge, skills and human resource development, access to financial resources, competence, and meaningfulness, self-determination, confidence, effectiveness, institutionalization, cooperation and collaboration and their subscales. The results revealed that the empowerment of local stakeholders affected tourism development and sustainability of rural settlements and tourist destination in marginal areas under study. However, 5 indicators of knowledge, skills and human resource development, competence, and meaningfulness, self-determination, and effectiveness were unable to explain sustainability and development in rural settlements. Thus, focus on these 5 indicators and their reinforcement along with other indicators among local stakeholders of tourism will increase their role in the development of rural settlements.
\end{abstract}

Keywords: empowerment, local stakeholders of tourism, sustainability, development of marginal rural settlements, Iran.

\section{INTRODUCTION}

Stakeholders and local suppliers who are experienced, trained and familiar with local attractions and the culture of local residents can act as intermediaries and guides for tourists. "Through participation and training as well as nurturing mutual understanding of clean environment and native culture of tourism settlements, these people play the role of facilitators to forge a friendly and constructive cultural relationship between tourists and residents of rural and urban settlements that provide services in tourism destinations" [1]. "In addition to increasing tourist attractions in destinations, due to the heightened attractiveness of tourist destinations, this promotes socio-economic stability and its progress towards sustainable tourism development" [2], [3].

"In recent decades, one of the most important strategies proposed for socio-economic and environmental sustainability and development of local settlements is the empowerment and participation of local stakeholders and suppliers in various dimensions" [4]. "This involves paying greater attention to indigenous knowledge of local residents and suppliers and raising their awareness to encourage cooperation and achieve socio-economic development" [5], [6]. "The participation of local stakeholders and suppliers, as one of the key non-governmental 
entities mediating the relationship between tourists and tourism destination, can affect sustainability and development of tourism settlements by promoting the trend and number of tourist" [7], [8]. "In addition, their close partnership with investors of tourism destinations through provision of environmental training and informing tourists about sustainability and mitigation of negative effects of tourism can also play a pivotal role in this regard" [9]-[11]. "Hence, tourism sustainability at local and regional levels can be achieved through prioritizing key objectives and participation of all agents for provision of tourism products" [12]. "Further, strengthening and developing relations with private sector investors and local organizations in tourist destinations can boost the productivity of these destinations and guarantee the sustainability of tourism in those areas" [13], [14].

In this regard, in recent decades, despite the relatively high proliferation of travel agencies in Tehran and Alborz, due to the disregard of tourism organizations, local tourism stakeholders and suppliers still struggle with a plethora of challenges that impede their participation in the field of tourism attraction and infrastructure development. These challenges are mainly related to offering basic training for appreciating and introducing tourism attractions of Tehran, tour management and their empowerment. "The absence of policies on participation of local tour managers and suppliers for investment in sustainable residential and entertainment infrastructure, lack of cooperation among local stakeholders, suppliers and investors in tourism destinations, and in general scant attention to local capacities and capabilities" [15] are some of factors contributing to the inadequate training, knowledge and control of tourists with regard to clean environment and environmental protection. These issues have compromised the sustainability and socio-economic development of tourism settlements in Tehran and Alborz.

Therefore, addressing issues associated with negative and detrimental effects of unsystematic planning without proper participation of local stakeholders and suppliers are of utmost importance for tourism sustainability. Therefore, this study was designed to explore the empowerment of local stakeholders and suppliers of tourism for greater participation and involvement in decision-making, as one of the factors affecting the sustainability and development of tourism destinations

\section{THEORETICAL BACKGROUND}

"The main goal of sustainable tourism development is to expand and manage tourism activities and services to create socio-economic benefits for local people and at the same time preserve attractions and benefits that help absorption of tourist" [16], [17]. "The idea of sustainability encompasses several dimensions, the most important of which are natural environment, socio-economic and cultural dimensions " [16], [18].

"Mowforth and Munt posits that in the process of sustainable tourism development, the diversity of sustainable development dimensions has to be taken into account. In this context, diversity encompasses socioeconomic, cultural and natural environment, as discussed below. 1 -Environmental sustainability: the necessity of avoiding or reducing environmental impact of tourism activities, which is achieved by calculating the bearing capacity, is an important way of estimating environmental and sustainability effects. 2 - Social sustainability: Promoting the ability of a society to attract tourists without causing abnormalities and disturbing balance in social relations" [19] "3 - Cultural sustainability: Promoting the capacity and ability of local people to maintain their native culture while interacting cultural groups from different regions. 4 - Economic sustainability: economic promotion of tourism activities that can sufficiently cover costs of service provision to tourists" [19], [20].

The goal of economic stability is to meet economic demands, desires and aspirations of local inhabitants in the long term. In this context, using local people can reinforce local 
employment and ensure the economic sustainability of the region [20]. Hence, tourism is one of rapid expanding industries in the world, which has contributed to economic, cultural and social development.

"Telfer and Sharply ague that tour managers and local suppliers, as providers of tourism services, through empowerment and participation in local development can play their part in improving environmental criteria, protecting the environment, and engaging local community in physical developments undertaken to promote local sustainability" [21]. "However, they need to be supported through constructive regulation and provision of facilities to create a sustainable environment" [22]. "The empowerment of local managers and suppliers not only helps their self-regulation, but also encourages growth and preparedness to accept further responsibilities in the future" [5], [23].

"In the literature on development, the concept of "empowerment" in relation to participation in socioeconomic activities has been studied from two perspectives: a) Motivational empowerment approach. In this approach, the aim is to nurture self-esteem. b) cognitive empowerment approach; this approach deals with empowerment at large scale as an intrinsic motivation in connection with jobs, which consists of four internal senses: 1) Meaning: it is when a person regards the performance of his/her duties as a meaningful and valuable act. 2) Competence: competence or self-confidence is a belief in the ability and capacity to get things done. 3) Impact: it refers to the ability of a person to affect and control the outcomes of his/her work. 4) Self-determination: It is the right to choose a personal feeling to regulate activities.

Although competence is a behavioural skill, it also refers to degree of freedom in determining activities required to perform job duties. 5) Confidence: Finally, confidence means that people feel that they have been treated fairly and equally" [24], [25].

In fact, empowerment offers potentials for self-reliance and self-confidence as opposed to dependency. "It is a process through which individuals, non-governmental organizations and marginalized groups can strengthen their institution and set themselves free of the domination of other structures or relationships" [26]. "For empowerment, a number of factors such as knowledge and organizational skills or training, proper procedures, subscription to organization, microcredits, confidence of individuals, education, access to resources and political support should be taken into consideration" [27]-[29]. Development theorist argue that the concept of empowerment is closely related to the concept of capacity-building. It is a permanent, flexible, effective and responsive process that require the participation of all actors. It is part of a multi-directional concept that implies several notions such as participation, protection, decentralization and privatization. Defining each of these concepts from the perspective of capacity- building as a process or paradigm to get closer to a definition of this concept requires particular attention on issues of power and power transmission. It is clear that a perquisite of any attempt to offer a pragmatic definition is deeper understanding of mental patterns and the coping strategy of local government with the concept of power transition.

"To achieve positive effects to capacity building, all three dimensions of human resource development, institutional development and organizational development have to be taken into account" [5], [30].

"Research on spatial impacts of empowering local stakeholders on the development of tourism and its positive and negative effects on development of rural settlements in tourism destinations have yielded varying results. "Giampoccolli is South Africa emphasized the role of external stakeholders in facilitating resource supply for empowerment of local stakeholders through training, so that they were allowed to take the control of affairs in their hand and improve infrastructure of tourism destinations. This reinforced self-confidence and 
therefore sustainability and improved quality of life of local stakeholders [7]". "In West Africa, the findings of Isaac et al. suggested that lack of skills, experience and access to resources and improper policy making for intervention of stakeholders in tourism activities are among barriers to participation of stakeholders in tourism activities, which can reduce the competence of local stakeholders" [31]. "In East Africa (Kenya) policies need to focus on individual and group empowerment of local stakeholder to achieve self-confidence and build trust" [32]. "Moreover, the leadership and guidance of local stakeholders to obtain selfdetermination is necessary" [33]. "In South America (Brazil) policies intended to protect the environment and improve quality of life were implemented through the intervention of local stakeholders in tourism activities "Mc Cool and" [34]. "In North America (Panama) reinforcing social networking of local stakeholders was shown to exert a significant impact on the sustainability of rural settlements" [35]. "In some south Asian countries such as India, cooperative groups have played a pivotal role in participation of stakeholders in tourism development" [36]. "In the Southeast Asia (Malaysia), there has been an emphasis on state support to grant loans for investments in areas such as tourism services and products" [37]. "In Eastern Asia, (China) government policies have been concentrated on investing in social capital and involvement of local stakeholders to improve the quality of life and sustainability in China's rural settlements" [38]. "In Eastern Europe (Poland) leaders play a vital role in guiding communities towards empowerment and sustainability, and policies need to be geared toward financial resources for empowerment of people in protecting the environment" [39]. "In Iran, scant attention of policy makers to empowerment of local stakeholders for participation in tourism development activities in marginal areas have contributed to the unsustainability of these areas" [40].

Based on the analysis of theoretical principles, a review of the literature is briefly presented. Assumes that the process of empowering local stakeholders of tourism with all its dimensions and indicators affect the sustainability and development of marginal rural settlements in an inter-connected and interactional manner.

\section{RESEARCH METHOD}

For a detailed explanation of the research hypothesis, this paper adopts a descriptiveanalytical analysis method to study the process of empowering local stakeholders and suppliers (affecting factor) on sustainability and development of settlements and tourism destination (affected factor) in marginal rural areas. The study population consisted of 192 local suppliers of tourism services, which were engaged in the provision of tourism services in Tehran and Alborz (see Fig. 1). These suppliers were identified through a field study and data released by Iran's Cultural Heritage and Tourism Organization.

"Given the subject of study and statistical population, a multistage sampling method was employed. The sample size was determined by Cochran's formula at a confidence level of $95 \%(n=128)$ with an estimated variance of 0.25 and desirable accuracy of 5\%" [41]. "Since the list of suppliers was available, the sample was selected on a systematic and random basis and the subjects were questioned directly. To determine the reliability of qualitative items, Cronbach's alpha coefficient was used $(\alpha=0.731)$ " [42].

"Also, the validity of items was evaluated based on face validity" [42] and the views of authorities of Cultural Heritage and Tourism Organization, university professors and tourism researchers. "Descriptive statistical methods were used for data analysis and the relationship between affecting and affected factors or the impact of empowerment and involvement of local stakeholders and suppliers on development of tourism destinations was determined by multivariate regression" [43]. 


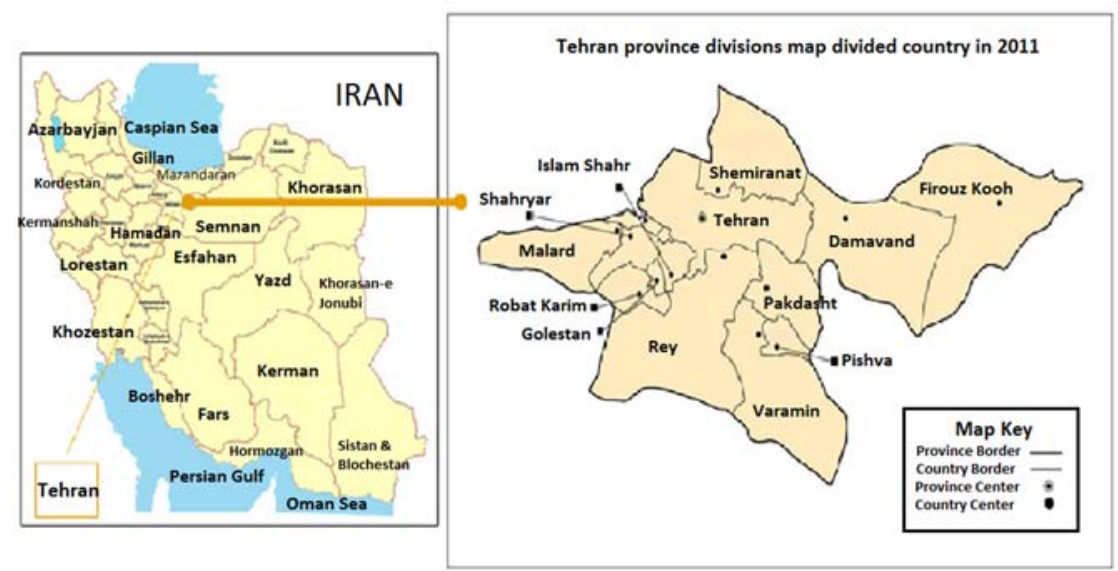

Figure 1: Geographical location of Tehran and Alborz.

Table 1: Indicators of empowerment of local stakeholders of tourism development.

\begin{tabular}{|c|c|}
\hline Indicator & Researchers \\
\hline $\begin{array}{c}\text { Training and } \\
\text { awareness-raising }\end{array}$ & $\begin{array}{l}\text { Zolfani, } 2015 \text { [23], Amoundsen \& Martinsen, } 2015 \text { [5], Rossberger } \\
\text { \& Krause, } 2015 \text { [27], Gonzala-Prendes \& Brisebois, } 2012 \text { [24], } \\
\text { Shafiei Sabet \& Haratifard, } 2015 \text { [40], Knight \& Cottrel, } 2016 \text { [30] }\end{array}$ \\
\hline Knowl & $\begin{array}{l}\text { Amdam, } 2005 \text { [44], Rossberger \& Krause, } 2015 \text { [27], Alkire et al., } \\
2013 \text { [45], Shafiei Sabet \& Haratifard, } 2015 \text { [40], Knight \& Cottrel, } \\
2016 \text { [30] }\end{array}$ \\
\hline $\begin{array}{r}\text { Access tc } \\
\text { and } \mathrm{c}\end{array}$ & $\begin{array}{l}\text { Kariuki, 2016, pp. 190-198 [28], Moscardo, } 2008 \text { [29], Jaafar et al., } \\
2015 \text { [37] }\end{array}$ \\
\hline Compe & $\begin{array}{l}\text { Fernandez \& Moldogaziev, } 2015 \text { [25], Amoundsen \& Martinsen, } \\
2015 \text { [5], Gonzala-Prendes \& Brisebois, } 2012 \text { [24], Strelezecka, } \\
2015 \text { [39], Knight \& Cottrel, } 2016 \text { [30] }\end{array}$ \\
\hline & $\begin{array}{l}\text { Fernandez \& Moldogaziev, } 2015 \text { [25], Amoundsen \& Ma } \\
2015 \text { [5], Gonzala-Prendes \& Brisebois, } 2012 \text { [24], Fway } \\
\text { [32], Knight \& Cottrel, 2016 [30] }\end{array}$ \\
\hline Self-d & $\begin{array}{l}\text { Fernandez \& Moldogaziev, 2015 [25], Amoundsen \& Martinsen, } \\
2015 \text { [5], Gonzala-Prendes \& Brisebois, } 2012 \text { [24], Giampoccolli, } \\
2012 \text { [7], Fwaya, } 2012 \text { [32], Knight \& Cottrel, } 2016 \text { [30] }\end{array}$ \\
\hline $\begin{array}{c}\text { Tru } \\
\text { conf }\end{array}$ & $\begin{array}{l}\text { Fernandez \& Moldoga } \\
2015, \text { Giampoccolli, } 2\end{array}$ \\
\hline Effec & $\begin{array}{l}\text { Fernandez \& Moldogaziev, } 2015 \text { [25], Amoundsen \& Martinsen, } \\
2015 \text { [5], Lezcano, } 2013 \text { [46], Gonzala-Prendes \& Brisebois, } 2012 \\
\text { [24], Knight \& Cottrel, } 2016 \text { [30] }\end{array}$ \\
\hline Institutic & $\begin{array}{l}\text { Rossberger \& Krause, } 2015 \text { [27], Amoundsen \& Martinsen, } 2015 \\
\text { [5], Claiborn, } 2010 \text { [35], Slathia, } 2015 \text { [36], Liu et al., } 2012 \text { [38], } \\
\text { Knight \& Cottrel, } 2016 \text { [30] }\end{array}$ \\
\hline $\begin{array}{l}\text { Cooperation and } \\
\text { collaboration }\end{array}$ & $\begin{array}{l}\text { Amoundsen \& Martinsen, } 2015 \text { [5], Sharma \& Kirkman, } 2015 \text { [26], } \\
\text { Fernandez \& Moldogaziev, } 2015 \text { [25], Slathia, } 2015 \text { [36], Shafiei } \\
\text { Sabet \& Haratifard, } 2015 \text { [40], Liu et al., } 2012 \text { [38] }\end{array}$ \\
\hline
\end{tabular}

Source:(Analysis of theoretical principles and literature review) 
Data analysis was performed by SPSS23 software. Based on the analysis of literature review and theoretical model of research, the effect of empowering local stakeholders and suppliers of tourism on the sustainability and development of marginal rural settlements was measured in terms of 10 indicators (Table 1). Moreover, factors affected by sustainability of rural settlements were measured in four dimensions (environmental-ecological, economic, sociocultural, physical and infrastructure).

\section{RESEARCH FINDINGS}

\subsection{Demographics of participants}

In terms of gender, of all fully-completed questionnaires collected from rural settlements in the study area, $74 \%$ were answered by men and $26 \%$ by women. As for age, respondents could be classified in five groups. In general, the mean age of respondents was 39 years and $35-45$ age group had the highest frequency, which accounted for $47 \%$ of respondents. The youngest and oldest respondents were 25 years and 59 years old. Also, with regard to the level of education, findings suggested that nearly $24.7 \%$ of the respondents had high school diploma and lower, $64.9 \%$ had bachelor degree and $10.4 \%$ had master degree and higher.

4.2 Evaluating the impact of empowering local stakeholders on tourism development and sustainability of marginal rural settlement

Moreover, the empowerment of local stakeholders (affecting factor) was measured using 10 indicators and their combined subscales. These indicators were derived from average responses of local stakeholders in the sample population (on a Likert scale ranging from 1 to $5)$.

4.3 The relationship between sustainability and development indices of marginal rural settlement and empowerment of local stakeholders of tourism

To analyse the relationship between indicators of empowering local stakeholder and indicators of rural development in studied area, Kendall's rank correlation coefficient was used. The results indicated a significant and positive relationship between empowerment of local stakeholders and development and sustainability of rural settlements and tourist destination in the marginal regions at a significance levels of 99 and 95\% (Table 2). Hence, increased development (in environmental, ecological, social, economic, physical and infrastructural dimensions) in rural areas under study was associated with enhanced empowerment of local tourism stakeholders.

Table 2: Relationship between development and sustainability of rural settlements and empowerment of local stakeholders of tourism.

\begin{tabular}{|c|c|c|c|c|c|c|}
\hline \multirow{2}{*}{$\begin{array}{l}\text { Dimensions of the } \\
\text { affected factor }\end{array}$} & \multirow{2}{*}{$\begin{array}{l}\text { Affecting } \\
\text { factor }\end{array}$} & \multirow[t]{2}{*}{ Mean } & \multirow[t]{2}{*}{ SD } & \multicolumn{2}{|c|}{ Kendall's Tau-b test } & \multirow[t]{2}{*}{ Relationship } \\
\hline & & & & Sig & $\mathrm{r}$ & \\
\hline $\begin{array}{l}\text { Environmental- } \\
\text { ecological }\end{array}$ & \multirow{4}{*}{$\begin{array}{c}\text { Local } \\
\text { stakeholders' } \\
\text { empowerment }\end{array}$} & 3.217 & 0.750 & $0.001 * *$ & 0.483 & Yes \\
\hline Social and cultural & & 3.184 & 0.612 & $0.011^{*}$ & 0.410 & Yes \\
\hline Economic & & 3.099 & 0.677 & $0.016^{*}$ & 0.384 & Yes \\
\hline $\begin{array}{l}\text { Physical and } \\
\text { infrastructural }\end{array}$ & & 3.355 & 0.762 & $0.000^{* *}$ & 0.522 & Yes \\
\hline
\end{tabular}

* Significant at 95\% level. ** Significant at 99\% level. 
Further, the analysis of the relationship between indicators of empowering local stakeholders and sustainability and development of rural settlements in tourism destinations based on the results of Kendall's Tau-b test suggested a significant and positive relationship at 90 and $95 \%$ levels of significance, as shown in Table 3. Hence, by taking measures to foster the empowerment of local stakeholders of tourism by improving their awareness, training, knowledge and skills, development of human resources, competence, meaning, selfdetermination, impact and effectiveness, institutionalization and participation in tourism villages under study, sustainability and the level of development in rural settlements can be increased.

\subsection{The final assessment of the impact empowering local stakeholders of tourism on} development and sustainability of rural settlement

To analyse and predict the impact of empowerment of tourism local stakeholders and development and sustainability of rural settlements and tourist destination in marginal areas under study and to identify principal variables, the multiple regression test was used. According to the results, there was a good correlation between sustainability and development of rural settlements in the study area and the empowerment of local stakeholders $(\alpha=0.586)$. Further, it explained $61.9 \%$ of variation in the dependent variable (i.e. sustainability and development rural settlements) induced by the empowerment of local stakeholders of tourism (Table 4).

Also, based on the estimated value of $\mathrm{F}$ at $95 \%$ confidence level, it can be concluded that in the view of respondents, the linear combination of affecting factors was able to explain and predict changes in the affected factors (i.e. the sustainability and development of rural settlements in the study area) (Table 5).

Table 3: Relationship between indices of empowering local stakeholders of tourism and development of rural settlements.

\begin{tabular}{|c|c|c|c|c|c|c|}
\hline \multirow{2}{*}{$\begin{array}{l}\text { Indicators of } \\
\text { empowering local } \\
\text { stakeholders of tourism }\end{array}$} & \multirow[t]{2}{*}{$\begin{array}{l}\text { Affecting } \\
\text { factor }\end{array}$} & \multirow[t]{2}{*}{ Mean } & \multirow[t]{2}{*}{ SD } & \multicolumn{2}{|c|}{$\begin{array}{c}\text { Kendall's Tau-b } \\
\text { test }\end{array}$} & \multirow[t]{2}{*}{ Relation } \\
\hline & & & & Sig & $\mathrm{r}$ & \\
\hline $\begin{array}{l}\text { Training and awareness- } \\
\text { raising }\end{array}$ & \multirow{10}{*}{$\begin{array}{c}\text { Local } \\
\text { stakeholders' } \\
\text { empowerment }\end{array}$} & 3.121 & 0.783 & 0.000 & 0.583 & Yes \\
\hline Knowledge, skill & & 3.097 & 0.821 & 0.014 & 0.420 & Yes \\
\hline Competence & & 2.103 & 0.419 & 0.113 & 0.107 & No \\
\hline Meaning & & 2.119 & 0.659 & 0.063 & 0.148 & No \\
\hline Self-determination & & 2.209 & 0.643 & 0.139 & 0.122 & No \\
\hline Impact and effectiveness & & 3.184 & 0.503 & 0.021 & 0.501 & Yes \\
\hline Trust and confidence & & 3.391 & 0.591 & 0.000 & 0.491 & Yes \\
\hline $\begin{array}{l}\text { Access to finance and } \\
\text { credits }\end{array}$ & & 3.012 & 0.513 & 0.019 & 0.408 & Yes \\
\hline Institutionalization & & 3.042 & 0.621 & 0.020 & 0.431 & Yes \\
\hline $\begin{array}{l}\text { Cooperation and } \\
\text { collaboration }\end{array}$ & & 3.23 & 0.719 & 0.000 & 0.528 & Yes \\
\hline
\end{tabular}

** Significant at 99\% level. * Significant at 95\% level. 
Table 4: Regression results of the parameters affecting of tourism and development and sustainability of rural settlements.

\begin{tabular}{|l|l|l|l|l|}
\hline Model & $\begin{array}{l}\text { Multiple correlation } \\
\text { coefficient I }\end{array}$ & $\begin{array}{l}\text { Coefficient of } \\
\text { determination } \mathrm{R}^{2}\end{array}$ & $\begin{array}{l}\text { Adjusted } \\
\text { coefficient of } \\
\text { determination } \mathrm{R}_{\mathrm{ad}}\end{array}$ & $\begin{array}{l}\text { Standard } \\
\text { error }\end{array}$ \\
\hline 1 & 0.586 & 0.682 & 0.619 & 0.242 \\
\hline
\end{tabular}

(a) predicators: awareness raising and training, knowledge, skills and human resource development, impact and effectiveness, confidence, access to finance and credit, institutionalization and associationbuilding, cooperation and collaboration.

Table 5: Significance of regression results for factors affecting of tourism and development and sustainability of rural settlements ANOVA (b).

\begin{tabular}{|c|c|c|c|c|c|c|}
\hline Model & & $\begin{array}{c}\text { Sum of } \\
\text { squares }\end{array}$ & df & $\begin{array}{c}\text { Mean } \\
\text { squares }\end{array}$ & F & Sig \\
\hline \multirow{2}{*}{1} & $\begin{array}{c}\text { Regression } \\
\text { effect }\end{array}$ & 132.701 & 5 & 26.540 & 272.413 & $0.010^{*}$ \\
\cline { 2 - 7 } & Remaining & 30.494 & 313 & 0.097 & - & - \\
\cline { 2 - 7 } & Total & 163.195 & 318 & - & - & - \\
\hline
\end{tabular}

(a) Predictors a: awareness raising and training, knowledge, skills and human resource development, impact, effectiveness, confidence, access to finance and credit, institutionalization, cooperation and collaboration.

(b) Dependent Variable: rural development *95\% significant level.

Table 6: Coefficients of the impact intensity of affecting and affected parameters (a) Coefficients.

\begin{tabular}{|c|c|c|c|c|c|c|}
\hline \multirow[t]{2}{*}{ Model } & \multirow[t]{2}{*}{ Description } & \multicolumn{2}{|c|}{$\begin{array}{c}\text { Standard } \\
\text { coefficient }\end{array}$} & $\begin{array}{l}\text { Standard } \\
\text { coefficient }\end{array}$ & \multirow[t]{2}{*}{$\mathrm{T}$} & \multirow[t]{2}{*}{ Sig } \\
\hline & & $\mathrm{B}$ & Std & $\beta$ & & \\
\hline \multirow[t]{6}{*}{1} & Intercept & 0.534 & 0.077 & - & 16.125 & $0.000^{* *}$ \\
\hline & $\begin{array}{l}\text { Training and awareness- } \\
\text { raising }\end{array}$ & 0.214 & 0.043 & 0.0378 & 10.982 & $0.000 * *$ \\
\hline & Trust and confidence & 0.221 & 0.035 & 0.0346 & 9.921 & $0.000 * *$ \\
\hline & $\begin{array}{l}\text { Access to finance and } \\
\text { credits }\end{array}$ & 0.201 & 0.039 & 0.203 & 6.876 & $0.006^{*}$ \\
\hline & Institutionalization & 0.229 & 0.095 & 0.288 & 12.145 & $0.003 *$ \\
\hline & $\begin{array}{l}\text { Cooperation } \\
\text { collaboration }\end{array}$ & 0.153 & 0.042 & 0.239 & 7.581 & $0.001 * *$ \\
\hline
\end{tabular}

(a) Dependent Variable: Sustainable Rural Development. $*=$ at $95 \%$ significant level. $* *=$ at $99 \%$ significant level.

Finally, based on the standardized coefficient defining the effect of empowering local stakeholders of tourism on development of rural settlements in tourism destination, it was observed that sustainability and development of rural settlements in study area was influenced by 5 parameters of empowerment of local stakeholders, among which training and awareness-raising $(\alpha=0.378)$ had the highest effect on sustainability and development of rural settlements in tourism destination in the marginal regions of Tehran and Alborz (Table 6).

Hence, based on the views of respondents, 5 parameters of knowledge, skills and human resource development, competence and meaning, self-determination, impact and 
effectiveness were failed to contribute to the sustainability and development of rural settlements. Given the significant and positive relationship between empowerment of local stakeholders of tourism and sustainability and development of rural settlements in tourism destinations in marginal areas under study, greater attention has to be paid to the promotion of these five parameters among local stakeholders of tourism in Tehran and Alborz region to contribute to the sustainability and development of settlements.

\section{CONCLUSIONS AND RECOMMENDATIONS}

In literature on development, it has been noted that the main purpose of empowering rural areas and local stakeholders of tourism is economic development and expansion of a range of activities in these tourism destinations so that local people can reap socioeconomic benefits and the sustainability and development of rural settlements is reinforced. Also, as discussed in the theoretical basis and literature review section, empowerment with a number of indicators such as training and awareness-raising, knowledge and skills, access to resources, competence, meaning, self-determination and effectiveness, among others, not only aid the development of tourism in the regions, but also improve the level of development in rural settlements. In this context, the present study explored the effects empowering local stakeholders of tourism based on development and sustainability of rural settlements in tourism destinations in marginal areas under study. The results of analysis indicated a significant positive relationship between the seven indicators of empowerment, including training and awareness-raising, knowledge, skills and human resource development, impact and effectiveness, trust and confidence, access to finance and credit, institutionalization, collaboration and cooperation and sustainability and development of rural settlements in areas under study in Tehran and Alborz.

Accordingly, reinforcing the empowerment of local stakeholders in rural areas under study was associated with improved sustainability and development indicators in these areas. Moreover, based on the results of regression analysis about predicting the effect of empowerment of local stakeholders of tourism on sustainability and development of rural settlements in tourism destinations within marginal areas under study, the effectiveness of indicators such as training and awareness-raising, trust and confidence, access to finance and credits, institutionalization, and cooperation in promoting rural development in study area was demonstrated. Thus, the present findings were consistent with the results of studies in: South Africa, Giampoccolli and Kalis Haywood [7]; West Africa, Manu and Kuuder [31]; Kenya in East Africa, Obonyo and Fwaya [32]; Central America, Matarrita-Cascante et al. [32]; South America McCool and Bosak [34]; East and South Asia; Slathia et al. [36]; Jaafar et al. [37]; and Eastern Europe; Strzelecki [6]. It should be noted that some affecting factors such as knowledge, skills and human resource development, competence, meaning, self-determination, impact and effectiveness have failed to explain development and sustainability of rural settlements in the region. As such, further studies are required to conform the findings of previous research.

Therefore, given the effects of empowering local stakeholders of tourism on sustainability and development of rural settlements in Tehran and Alborz regions, further attention has to be paid to knowledge, skills the development of human resources, competencies, meaning, self-determination, impact and effectiveness in these areas to improve their socio-economic function. Consistent with the literature on development, this study stressed the importance of empowering local stakeholders of tourism in promoting environmental-ecological, social and cultural, economic and environmental indicators. In this regard, sustainable development through the adoption of appropriate social and economic policies by the government can also be effective. Therefore, understanding the relationship between local stakeholders in rural 
areas and external urban stakeholders can contribute to structural and functional changes as well as their interactions with the aim of forming and expanding residential and entertainment facilities and encouraging sustainable policy-making by the government, which in turn inspire community-based development in rural tourism. In addition, local governments in Tehran and Karaj are recommended to pay greater attention to local initiatives and make planning for the development and expansion of community-based tourism in line with enhanced empowerment of local stakeholders of tourism to increase balance development of rural settlements in tourism destinations.

We also found that the type and manner of empowering local stakeholders to develop sustainable tourism and sustainability of rural settlements development in tourism destinations area under study differed from their counterparts in Europe and East Asia, South America and Central Africa.

\section{REFERENCES}

[1] Nazrin, A., Anuar, A. \& Ahmad, H., Understanding the Factors Influencing Formation of Tourist Friendly Destination Concept. Journal of Management and Sustainability, 2(1), pp.106-114, 2012

[2] Selanniemi, T., Sustainable tourism: the tour operator contribution, Paris, pp. 1-97, 2003.

[3] Breugel, L. Van., Community-based tourism: Local participation and perceived impacts, Faculty of Social Sciences, Radboud University Nijmegen, pp. 1-82, 2013.

[4] Waligo, V.M., Clarke, J. \& Hawkins, R. Implementing sustainable tourism: A multistakeholder involvement management framework. Tourism Management, 36, Elsevier Ltd., 2013.

[5] Amundsen, S. \& Martinsen, L., linking empowering leadership to job satisfaction, Work Effort, and Creativity: The Role of Self-Leadership and Psychological Empowerment. Journal of Leadership and Organizational Studies, 22(3), pp. 304-323, 2015.

[6] Strzelecki, M., Individual and Community Empowerment Enhancement in Sustainable Tourism Development in Post-Community Poland, Dissertation, University of Illinois at Urbana-Champaign, pp. 1-182, 2012.

[7] Giampiccoli, A. \& Kalis Hayward, J., Community-based tourism and local culture: the case of the amaMpondo, Pasos. Revista de Tourism Patrimonial Cultural, 10(1), pp. 173-188, 2012.

[8] Fredericks, L., Garstea, R. \& Monforte, S., Sustainable Tourism Destinations: A Pathway for Tour Operators, Master thesis of Blekinge institute of technology, Karlsrona, Sweden, pp. 1-81, 2008.

[9] Budneau, A., Environment supply chain management in tourism: the case of large Tour operators. Journal of Cleaner Production, 17(16), pp. 1385-1392, 2009.

[10] Bramwell, B. \& Lane, B., Tourism Collaboration and Partnerships: Politics, Practice and Sustainability. Journal of Vacation Marketing, Channel View Publications, 7, 2001.

[11] Kosak, N., Collaboration and Rural Development in the Tourism Context Tourism Development, Cambridge Scholar Publishing, pp. 161-175, 2015.

[12] Graci, S., Collaboration and Partnership Development for Sustainable Tourism. Tourism Geographies, 15(1), pp. 25-42, 2013.

[13] Janeth, C., Relationship Marketing and selected performance indicators of tour operators. A case study of Nairobi county, university of Nairobi, pp. 1-73, 2013.

[14] Redclift, M., \& Springett, D., Routledge International Handbook, Routledge, pp. 1427, 2015. 
[15] Lusby, C. \& Eow, K., Tourism Development in a New Democracy: Residents' Perceptions of Community-based Tourism in Mawlamyine. Myanmar. Journal of Tourism and Recreation, 2(1), pp. 23-40, 2015.

[16] WTO, Why tourism? UNWTO's website, pp. 1-16, 2013. http://www2.unwto.org/en/ content/why-tourism. Accessed on: 2 Feb. 2012.

[17] Tour Operators Initiative, Integrating sustainability into business, Management guide for responsible tour operators, United Nations, pp. 1-63, 2005. http://www.toinitiative. org/fileadmin/docs/publications/Sustainability_in_Business_Management.pdf.

Accessed on: 15 Aug. 2009.

[18] Muresan, I.C., et al., Residents' Attitude Toward Sustainable Rural Tourism Development, pp. 1-14, 2016.

[19] Wang, S., Lee, M., Château, P. \& Chang, Y., Performance Indicator Framework for Evaluation of Sustainable Tourism in the Taiwan Coastal Zone, 2016.

[20] Dangi, T. B. \& Jamal, T., An Integrated Approach to "Sustainable Community-Based Tourism, MDPI. Sustainability, 8(475), pp. 1-32, 2016.

[21] Telfer, D. \& Sharpley, R., Tourism and Development in the Developing World, Routledge, Oxon, UK, pp. 1-280, 2008.

[22] UN, Report of the United Nations Conference on Sustainable development. 1-120. [Report]. In: RIO+20, United Nations conference on sustainable development. Rio de Janeiro, 20-22 June 2012. New York: 2012. UN. Available via: http://www.uncsd2012.org/content/documents/.

[23] Zolfani, S., Sedaghat, M., Maknoon, R. \& Zavadskas, E., Sustainable tourism: a comprehensive literature review on frameworks and applications Economic Research. Ekonomska Sustainable tourism, 28(1), pp. 1-30, 2016.

[24] González-Prendes, A. \& Brisebois, K., Cognitive-Behavioral Therapy and Social Work Values: A Critical Analysis.Journal of Social Work Values \& Ethics, 9(2), pp. 2133, 2012.

[25] Fernandez, S. \& Moldogaziev, T., Employee Empowerment and Job Satisfaction in the U.S. Federal Bureaucracy: A Self-Determination Theory Perspective. The American Review of Public Administration, 45(4), pp. 375-401, 2015.

[26] Sharma, P.N. \& Kirkman, B.L., Leveraging Leaders: A Literature Review and Future Lines of Inquiry for Empowering Leadership Research, Group Organization Management, 40(2), pp. 193-237, 2015.

[27] Rossberger, R.J. \& Krause, D.E., Participative and Team-Oriented Leadership Styles, Countries' Education Level, and National Innovation: The Mediating Role of Economic Factors and National Cultural Practices, Cross-Cultural Research, 49(1), pp. 20-56, 2015.

[28] Kariuki, M., Empowering the Kenyan People through Alternative Dispute Resolution Mechanisms, Government Printer, Nairobi, pp. 1-36, 2015.

[29] Moscardo, G., Building Community Capacity for Tourism Development, Cabi, USA, pp. 1-197, 2008.

[30] Knight, D.W. \& Cottrell, S.P., Evaluating tourism-linked empowerment in Cuzco, Peru. Annals of Tourism Research, Elsevier Ltd, (56), pp. 32-47, 2016.

[31] Manu, I. \& Kuuder, W.C.J., Community-Based Ecotourism and Livelihood Enhancement in Sirigu, Ghana. International Journal of Humanities and Social Science, 2(18), pp. 97-108, 2012.

[32] Obonyo, G.O. \& Fwaya, E.V.O., Integrating Tourism with Rural Development Strategies in Western Kenya. American Journal of Tourism Research, 1, 2012. 
[33] Matarrita-Cascante, D., Brennan, M.A. \& Luloff, A.E., Community agency and sustainable tourism development: the case of La Fortuna, Costa Rica. Journal of Sustainable Tourism, 18(6), pp. 735-756, 2010.

[34] McCool, S., Bosak, S., Reframing Sustainable Tourism, Spring, New York, London, pp. 1-257, 2016.

[35] Toro, B. \& Claiborne, P., Community Participation in Tourism Development and the Value of Social Capital Master of Science in Tourism and Hospitality Management Master Degree Project, pp. 1-84, 2010.

[36] Slathia, P.S., Paul, N \& Nain. M.S., Socio-economic Empowerment of Rural Women Through Rural tourism Projects in Jammu Region of J \& K State in India. Indian Journal of Extension Education, 51(3,4), pp. 40-43, 2015.

[37] Jaafar, M., Bakri, N.M. \& Rasoolimanesh, S.M., Local Community and Tourism Development: A Study of Rural Mountainous Destinations. Modern Applied Science, 9(8), pp. 399-408, 2015.

[38] Liu, W., Vogt, C.A., Luo, J., He, G., Frank, K.A. \& Liu, J., Drivers and Socioeconomic Impacts of Tourism Participation in Protected Areas. PLoS ONE ,7(4), pp. 1-14, 2012.

[39] Strzelecka, M. \& Strzelecka, C., Empowerment's Influence on Resident Support for Tourism in rural Central and Eastern Europe (CEE), 10(3), pp. 78-97, 2016.

[40] Shafiei Sabet, N., Haratifard, S., The Impact of Cooperation of Tour Operators in Sustainability and Development of Local Settlements, Tourism Planning and Development, 5(13), pp. 93-115, 2015.

[41] Saraiei, H., Introduction to survey sampling in research, Samt Publication, Tehran, 1996.

[42] Hafeznia, M., Introduction to survey sampling, Samt Publication, Tehran, 2009.

[43] Kalantari, K.H., Analysis of data in social-Economical Research, Sharif, Tehran, 2006.

[44] Amdam, J., Spatial planning in rural areas. In Collection of Papers-AESOP 2005 Congress, Vienna University of Technology, Austria, 2005. Available on: http://www.hivolda.no/neted/upload/attachment/site/group1/notat9-05.pdf

[45] Alkire, S., Meinzen-Dick, A., Peterman, A., Quisumbing Saymour, A. \& Vas, A., The Women's Empowerment in Agriculture Index. World Development, 52, pp. 71-91, 2013.

[46] Aguinaga Lezcano, P.A., Do Self-Help Groups Work on Achieving Economic Goals? New Evidence from A Field Experiment In Medellin, Colombia, Master Thesis International and Development Economics, University of San Francisco, 2013. 